\title{
Ethnic Albanian rings of organised criminals and the trafficking and smuggling of human beings: an international, regional and local perspective
}

\begin{abstract}
Located on the Balkan peninsula in south-eastern Europe, in a perfect situation bridging east and west, with more than three-quarters of the country mountainous and about $40 \%$ of the land forested, and with access to the Adriatic and lonian Seas and proximity to Italy and Greece, Albania after the fall of the Communist regime and the opening of the borders became a haven for different types of trafficking. The trafficking of women and children became a major issue from the 1990s. In the period between 1997 and 2001, Albanian organised crime groups operating in western Europe reached their peak. Nowadays, Albanian OC groups continue to be involved in trafficking and smuggling of human beings. Albania is no longer an important transit or destination country, but it remains an origin country for the trafficking of young women for sexual exploitation.
\end{abstract}

Keywords: Albanian OC groups, trafficking, smuggling, re-trafficking, origin/ transit/destination country, sexual exploitation.

\section{Introduction}

After the collapse of the Communist regime in 1990, Albania was engulfed by deep conflicts, crises and disturbances of a political, social, economic and security nature. With the opening of its borders, the country was faced with an emigration of almost biblical proportions, both legal and illegal, to European countries, initially to Greece and Italy and from there to other European nations. The first wave occurred in the early ' 90 s, when several embassies in Tiranë were occupied by several thousand people asking for political asylum in other European countries. This was followed by large groups of people emigrating towards Greece and a massive wave of Albanian emigrants using the main sea ports to reach Italy. ${ }^{1}$ This initial mass movement out of Albania was partly for political reasons, but the vast majority who left did so to seek work and earn more money than they could in Albania.

At that time, illegal migration was not considered a serious offence in Albania and smuggling channels were perceived as 'beneficial'. This, along with the lack of experience in the building of a modern democracy, particularly a police service, and a lack of international attention, introduced incentives for the smuggling of migrants.

Albanians, who were used to living in a Stalinist and isolationist state with no freedom of thought and opinion and under hard living conditions, suddenly came into

1 According to the Italian authorities, there are about 350000 officially registered Albanian citizens currently living in Italy of whom 152000 are females. 
contact with high European standards and were determined to get those benefits as soon as they could. With a view to faster enrichment and easy money, they were involved in minor and serious crimes and quickly developed criminal networks and links to other criminal organisations. This, in turn, led to the spread of Albanian criminal tentacles.

The question arises why there was such a sudden outburst of Albanian criminality. First of all, the disruption and breakdown of the activities of the Italian Mafia provided the opportunity for other ethnic-based crime groups to move in. Secondly, Albanians, particularly Kosovars, began to develop the sense of collective identity required for these groups to mobilise their activities. The virulent anti-Albanian campaign of the early '90s served to radicalise Kosovars. Thirdly, the process of democratisation that swept throughout eastern Europe in 1989-1990 began later in Albania. The country's efforts at democracy and providing basic foodstuffs for its population preoccupied the government, and an unfortunate by-product of this period became the increasing levels of crime.

On the other hand, hostility toward Albanian communities overseas reinforced ties among them. Feeling excluded abroad, they saw crime as the only possible way to emerge. The hierarchical, homogenous and almost exclusively ethnic group structure; deftness and speed in actions; the use of moral and physical violence and/or brutal forms of blackmail; rigorous discipline, individual submission and strict and maximum caution; links between all members based on loyalty, honour and clan traditions (and the use of the Kanun to ensure allegiance ${ }^{2}$ ); and the involvement in multiple criminal activities facilitated the supremacy and rapid escalation of Albanian organised crime in Europe and elsewhere. The trafficking of human beings, mainly women and girls for prostitution, and drugs trafficking became the principle business of Albanian criminal groups.

The second wave of legal (the 'brain drain') and illegal (the spread of Albanian criminal tentacles) mass emigration occurred in 1997, after the collapse of the pyramid schemes. With the complete breakdown of the state, the destruction of infrastructure, borders uncontrolled or in the hands of gangs and three quarters of a million weapons looted from army depots, chaos was spread all over the country and criminality and corruption became embedded in the Albanian government and in society. This created an ideal environment for criminals in many regions of Albania to develop their criminal activities, including trafficking in human beings. The largest sea ports were used as main routes for the transport of victims by speedboat. Another characteristic of the short-lived rebellion of 1997 was that there was an upsurge of migrants fleeing for their personal safety.

The result was that the number of women trafficked for the purpose of exploitation and prostitution increased and unchecked competition among traffickers commenced. Additionally, armed vigilante groups started on revenge attacks and to pro-

2 I personally think that this is, in fact, a misuse of the Kanun, the old Albanian customary laws. All that is happening is not due to or according to the Kanun, but the improper functioning of the state allows criminals to use it as a shield. Criminal offences currently committed by Albanian perpetrators and/or organised groups have nothing to do with the application of the Kanun, but with killers and murderers who use the Kanun blood feud as an alibi. 
tect girls from the threat of trafficking. It became very difficult and dangerous to recruit Albanian girls, so perpetrators drew their attention to foreign women, mostly from eastern Europe where it was much easier to take advantage of their wish to go to the west.

The third wave of mass migration occurred during the Kosovo conflict that took place between 1998-1999. During the crises in Kosovo, more than half a million of Kosovar refugees entered Albania while many Albanian citizens migrated to Europe claiming Kosovar nationality. The crises in Kosovo mainly introduced incentives for weapons trafficking; however, trafficking and the smuggling of people flourished as well.

Several international media outlets, journals, research studies, papers and articles were focused on the Albanian exodus, mass illegal emigration and criminality. Albanians were often depicted as 'people of rubber boats'.

Concrete steps and a real response to the trafficking of human beings were undertaken after 2001-02, when several initiatives were introduced to improve the legislative, institutional and strategic framework and to encourage inter-agency and international co-operation in order to address more effectively the trafficking of human beings. Notably, these initiatives include:

- the incorporation of trafficking in human beings as a criminal offence in the Albanian legislation (2001) and several other legislative reforms

- joint police operations with other national and international law enforcement agencies (2002 onwards)

- the creation of the Directorate of the Fight against Organised Crime and of Witness Protection within the Albanian State Police (ASP) structure (2004)

- the adoption of the National Strategy for Combating Trafficking in Human Beings ${ }^{3}$ - Strategic Framework and National Action Plan: 2005-2007

- education initiatives amongst vulnerable, unemployed and lowly-educated women in rural areas

- the establishment of the National Victim Referral Mechanism (2006)

- the establishment of the Responsible Authority ${ }^{4}$ and the setting-up of regional committees in the fight against trafficking in human beings strategy (2006)

- the ratification of several international conventions and other bilateral agreements with neighbouring countries. ${ }^{5}$

Crime statistics indicate that, since 2001, there has been a constant decrease in offences related to people trafficking, although illegal migration still remains a matter of concern, especially along Albanian-Greek green borders. ${ }^{6}$ Poor economic conditions in Albania and the strict visa regime in Greece force hundreds of 'work migrants' to cross illegally the land border with Greece, the only neighbouring EU member state.

3 This also includes the National Strategy for Combating Trafficking in Children.

4 This is composed of the Ministries of the Interior, Labour and Foreign Affairs and is tasked with monitoring the referral process and providing assistance and protection in order to integrate victims and potential victims.

5 Co-operation Protocols exist with Kosovo, FYROM, Montenegro and Greece to assist victims.

6 It is fair nowadays to replace the term 'trafficking' with the term 'smuggling'. 


\section{Ethnic Albanian OC groups involved in the trafficking and smuggling of human beings}

The ethnic Albanian OC groups involved in the trafficking and smuggling of human beings have undergone several development stages. During the first stage, immediately after the fall of Communism (from 1991-1996), the first organised criminal groups were established which were mostly active in the smuggling of people from Albania. This covered illegal immigration mainly to Greece and Italy. About 25 criminal organisations based mainly in Vlorë grew out of the emigration flows. During the second stage (1997-2001), Albanian OC groups were active in the smuggling and trafficking of human beings, including foreigners, from and through Albania to various EU countries. Until 2001 (the peak), it is estimated that 100000 people were trafficked either from or through Albania to various EU countries. In 2002 (stage 3), police, prosecution and other regional/international law enforcement agencies organised joint operations aimed at reducing the trafficking and smuggling via speedboats in Albania almost to zero. ${ }^{7}$

After 2003 (the current stage), significant progress has been made in combating the trafficking and smuggling of human beings. A number of criminal groups have been prosecuted and dismantled. However, Albanian OC groups are still involved in trafficking and, mainly, smuggling of human beings. Albania is no longer an important transit or destination country but it continues to be an origin country for the trafficking of women for sexual exploitation.

Albanian criminal groups are now complex organisations with fluid and flexible structures. Violence, hierarchy, homogeneity and exclusive ethnicities are no longer the core characteristics of ethnic Albanian OC groups; they are adapting to the sociopolitical environment of western Balkan countries. For instance, they have changed the way they manage the business of trafficking. Increasingly, victims and traffickers travel with valid documents using legitimate routes and crossing official border points using vehicles, airplanes and ferries.

The criminal groups involved both in the trafficking and smuggling of people are composed of 3-7 members. They are based on friendships and family relations, but only the head of a group has a permanent position: other members move from one group to another dependent upon tasks and requirements. Tasks are delegated to particular members of the group dependent upon skills. There are members recruiting people (recruiters); providers of transport to borders (transporters); members who accompany people while crossing borders (guides); and members who accompany people to the territory of other states.

The most extensive concentration of organised criminal groups involved in both the trafficking and smuggling of people is in the southern region of Albania (Gjirokastra), but often criminal groups from one region act also in other regions. Re-

7 In 2002, Albanian State Police organised nine operations in the fight against illegal trafficking. Two of them were regional operations ('Mirazh 1' and 'Plowshares') carried out in the framework of SECI Centre. Others ('Puna', 'Gjuetia e Çakejve' and 'Liqeni') were carried out in co-operation with other national law enforcement agencies. Forty eight criminal groups were disrupted. Two hundred women were rescued from trafficking (12 foreigners) and 486 women were returned from other countries, of whom 453 were settled in rehabilitation centres and 31 were integrated into society. 
cently, some organised criminal groups involved in the trafficking of human beings have been disrupted by police activity or have changed the commodity and are involved in other crimes. Membership of organised criminal groups is composed mostly of criminals of Albanian nationality and citizenship, but in the border regions there are also citizens of neighbouring countries or former Albanian nationals who now have citizenship in neighbouring countries. ${ }^{8}$

Almost all organised criminal groups are/were multi-crime oriented. Besides the trafficking of human beings, they are/were involved in a variety of other crimes such as the trafficking of guns, vehicles and drugs; money laundering; the smuggling of people; and the falsification of documents.

\section{Modus operandi}

The use of couples - trafficker and victim - was a typical form of Albanian trafficking in the past but now there is a more organised network in which victims are recruited by individual traffickers but managed collectively.

In several regions, perpetrators act like individual criminals but co-operate strongly with other criminals. In comparison to some other countries with strong structured organised groups, current cases of the trafficking of Albanian women show that there are 1-3 perpetrators involved who recruit a victim, ensure transport and facilitate a legal or illegal border crossing.

In other cases with a strong international dimension, at least 3-6 people are involved and monetary transfers are carried out in cash. Sometimes even 2-3 relatives work together and exploit women. Cases when the family is aware of the exploitation of a daughter abroad are known. For example, Roma families are actively involved and have an economic thinking about the trafficking of children and sexual exploitation of girls.

Perpetrators of Albanian nationality are, mostly, the first link in the chain but, at the later stage in transit or destination countries, foreigners or emigrants are involved. Both men and women are involved, but with different roles. Women take on different roles as recruiters, mediators and supervisors. In particular, they facilitate the recruitment process. In destination countries, some women take on the role of supervisor.

As regards crossing the green border, there is a person available in every region called the 'dealer', as a first link in the chain of a smuggler group and the first point of contact between 'smuggled people' and smugglers. The dealer is responsible for financial arrangements and organises the whole process.

For smuggling people to Italy through Greece, the mountainous green border from Albania to Greece is crossed and migrants are subsequently transported to Italy by ferry. The whole process is well organised, with the involvement of other criminals providing fake documents for migrants. Fake documents are delivered either in Albania but, mostly, in Greece. In Athens, there are Albanian criminals specialised only in the production of forged documents. Albanian immigrants living in Italy facilitate the smuggling process. Sometimes immigrants pay a part of the price for their smuggling

8 Thus, criminal groups in the north-eastern region (Kukës) have some members from Kosovo; Albanian citizens of Greek nationality are members of organised criminal groups operating in the south (Gjirokastër); and some members of criminal groups active in the north-western region (Shkodër) come from Montenegro. 
in Albania and part in Italy. Bearing in mind the tough conditions for the integration of illegal migrants in destination countries, it is assumed that, through a procedure for payment partly after their arrival in destination countries, there is a risk and space for the exploitation of those who are not able to pay the full price.

\section{Legitimisation of illegal proceeds}

Members of organised crime groups often invest profits from the exploitation and trafficking of people in legitimate business ventures, e.g. bars and restaurants. Due to their previous illegal activities and contacts within the criminal environment, the potential for using such 'legal premises' for the exploitation of women for prostitution is significant. Another form of re-investing the money is its use in another field of criminality. Many drug traffickers started their criminal careers with the exploitation of women for prostitution, where the potential for profit is huge.

It is said that the strength of the local currency is derived from three sources:

1. money from workers abroad sent back to their families (remittances), which represents approximately $1 / 5$ of GDP

2. money sent via projects of the EU and other international donors; and, above all:

3. money generated from criminal activities, mainly illegal trafficking and smuggling.

Albanian organised criminal activities are strongly linked with the unknown scale of the grey or informal economy. It is estimated that economic and financial crimes such as fiscal evasion, money laundering, corruption and falsification are currently the most widespread forms of organised criminality. These types of crime heavily rely on the weakness of the Albanian banking system, tax and customs institutions.

Albania is a base of operations for the conduct of criminal activities in other countries, and the proceeds from these activities are laundered in Albania. ${ }^{9}$ Criminal assets are often introduced in the Albanian economy through the purchase of land and property, tourist agencies, nightlife services, shopping centres, TV/radio networks, business investments, etc. The construction industry remains particularly vulnerable. On top of that, Albania remains largely a cash economy: about $33 \%$ of the money in circulation is outside the banking system.

\section{Re-trafficking and internal trafficking}

It is reported that many victims, either before or after being provided with assistance and leaving rehabilitation centres, are re-trafficked. Assistance providers believe that the main reasons for the re-trafficking of returned women is a combination of a lack of support from their families and insufficient support from the government. They perceive negatively the experience that, in spite of the denouncements of perpetrators and exploiters, these are not punished properly.

There is also the issue of the insufficient protection of victims, in cases when women have denounced traffickers, as one of the reasons behind re-trafficking. A certain number of women have been re-trafficked to eliminate risks to their lives.

Another problem occurs when, even if assistance is provided to women and they are able to be re-integrated in the working process, their income is again too low and

9 According to some sources, it is estimated that there is approximately $\$ 15-18$ bn in Albania waiting to be laundered. 
they either find old connections to traffickers or else the perpetrators themselves find them and re-traffic them.

Re-trafficking has different forms; women are either re-trafficked abroad or within the country. On the one hand, the number of internationally-trafficked victims is decreasing, but the current phenomenon is that victims are increasingly exploited in Albania.

\section{Trafficking of women}

There are several 'push factors' in why some regions of Albania became centres for trafficked women in the past. One of the most important was, and still is, the economic situation in some regions and for some social groups (the Roma community), as well as the desire to find the possibility of a better living standard, mostly abroad. Unemployment and poverty are seen as major contributors to the vulnerability of women to becoming victims of trafficking.

Over the last few years, especially since the establishment of the legislative and institutional framework for fighting this negative phenomenon, there has been a decrease in the cross-border trafficking of women and girls for the purpose of exploitation for prostitution. Some organised groups have been disrupted recently: their members have left the country or else changed the commodity of their illegal activity. However, there are still cases of trafficked victims being repatriated and deported, mainly from EU countries.

The exploitation of women reaches a higher level in the capital and cities where there is a demand for sexual services. Increased efforts to address the cross-border trafficking of Albanian women have resulted in a decreased number of these cases but an increase in the exploitation of women for prostitution in Albania as perpetrators seek alternative business opportunities. This change of modus operandi has been visible since the establishment of the Serious Crime Court and facilitated by the availability of premises from which to conduct business, such as bars in some cities. The punishment for trafficking offences is higher than that for the exploitation of prostitution, so perpetrators very quickly calculate the lower risk of exploiting victims in the country.

An obstacle to investigation is the reluctance of women to denounce exploiters. This occurs both in cases of forced exploitation and cases where there is an agreement with the perpetrator for the woman to receive a certain percentage of the profit.

\section{Related offences to trafficking in human beings}

Generally, the crime statistics of the Albanian State Police do not provide a clear picture of the real level of criminality: there are discrepancies in its presentation by different institutions, e.g. the data of the Ministry of the Interior and those of the General Prosecution Office.

One of the quantitative indicators in assessing whether the trend is increasing or decreasing is the number of trafficking-related offences. ${ }^{10}$ These figures reflect only known cases, so they do not indicate the real extent of the phenomenon.

10 The extent of trafficking can also be measured from the numbers of women/children deported from foreign countries to Albania and the victims of trafficking identified among them. These data are incomplete, so have not been presented in this paper. 
Systematic data recording commenced in 2004, following the legislative and institutional reforms initiated in the ASP.

Figure 1 - Number of cases reported: trafficking/smuggling of human beings, 2004-2007

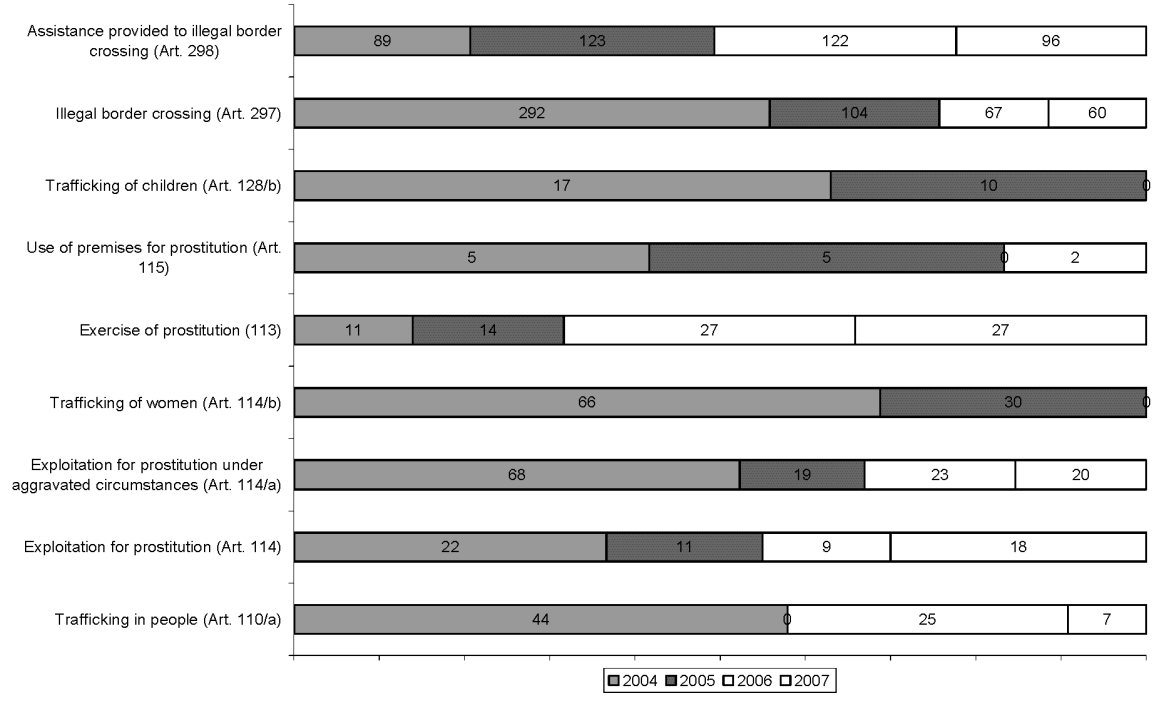

Figure 1 shows that there has been a constant decrease in criminal cases of the trafficking of people. The trafficking of children (mainly in the Roma community) for begging and of young women for prostitution still constitutes a day-to-day concern for the ASP, while the smuggling of people continues and its extent is not known.

\section{Related offences to the smuggling of human beings ${ }^{11}$}

After 2004, there has been a decrease in the total number of criminal cases of illegal border crossings (see Figure 1).

Concerning the offence of providing assistance for illegal border crossing, there was an increase in the total number of cases in 2005 in comparison to 2004, following which there was a slight decrease in 2006 and 2007 compared to 2005. The increased statistical figures do not necessarily always mean an increase in a particular crime in general: higher detection rates are sometimes the consequence of improved border management, the increased efforts of law enforcement or the use of new detection methods and special equipment.

Increased or decreased trends in illegal migration need to be compared with the data provided by the authorities in the respective countries in which Albanian citizens have entered or in which they unlawfully reside. Therefore, it is acknowledged by

11 Criminal offences related to the smuggling of human beings are stipulated in Articles 297 (Illegal Border Crossing) and 298 (Providing Assistance for Illegal Border Crossing) of the Albanian Criminal Code. 
the ASP authorities that the extent of smuggling is not known. Nevertheless, the smuggling of human beings remains a phenomenon connected to the poverty factor as well as the restricted freedom of movement for Albanian citizens.

In the Albanian context, illegal migration has been considered as a solution to an immediate problem. It is part of the strategy of an Albanian household. The large sums of money that Albanian migrants pay and the risks they take indicate their determination to find work, earn and save money and help themselves. Currently, emigrants' remittances to Albania are estimated to represent about 15-20\% of GDP. This is indicative of work migration being one of the main sources of income generation for a considerable number of households in Albania. Therefore, without a more sophisticated approach to work migration, illegal migration will continue to be a wager which Albanians might lose, but in the context that they know they will definitely lose if they do not migrate.

\section{Trafficking and smuggling routes}

In general, the identified routes used for the smuggling of people are often identical with those used for the smuggling of illegal goods. For a period of time between 1990 and 2002, the illegal trafficking and smuggling of people from Albania mainly via 'sea routes' to Italy and Greece was typical. At present, however, the 'sea routes' are more used for the transportation of cannabis and heroin. ${ }^{12}$

Following several measures taken by the government, ${ }^{13}$ new routes to bringing victims out of Albania have been discovered.

Current land routes towards the main destination countries used by traffickers are as follows:

- Albania - Italy

- Albania - Greece - Italy

- Albania - Macedonia - Greece, and through Piraeus to western European countries

- Albania - Italy - Belgium - Netherlands - United Kingdom

- Albania - Montenegro - Croatia - Slovenia - Italy

- Albania - Kosovo - Serbia - Croatia - Slovenia - Italy/other EU countries (Belgium, Germany, England)/Switzerland - USA - Canada

Both the legal crossing of borders through border crossing points and illegal crossings via green and blue borders are used by traffickers. In border crossings through border crossing points, fake documents are predominantly supplied. Supplying traffickers and smugglers with fake documents is an important service provided by other criminals.

12 According to police findings in Italy, only one speedboat carrying illegal migrants, trafficking victims and drugs reaches the Italian coast each week. The price for such services has increased dramatically and is now thought to be between $€ 1000$ and $€ 2500$.

13 The decreased trend of using 'sea routes' and the search for other trafficking and smuggling routes is connected both with the legislative measures adopted and counter-trafficking efforts undertaken by the Albanian government (Moratorium on Vessels; establishment of the Anti-Trafficking Centre in Vlora). 


\section{International dimension of Albanian $\mathrm{OC}$ groups}

There are links between organised criminal groups in Albania especially with criminals in neighbouring countries and in some destination countries. Of concern is that Albanian criminal groups abroad have a very strong structure and links in several countries. Unlike the Italian Mafia abroad (e.g. in the US during the last century), which operates independently of Mafia groups in the homeland (Italy), Albanian OC groups operating abroad have strong links with, and are managed from, homeland OC groups. Due to the development of the communications infrastructure, a lot of work is done in Albania.

According to the Italian authorities, even if Albania is no longer the main country of origin and transit for victims of trafficking, the network for the sexual exploitation of women in Italy is managed mainly by Albanian criminals. Albanian perpetrators constitute $29 \%$ of foreigners under investigation, arrested and sentenced for people trafficking-related offences.

Ethnic Albanian criminal groups operating abroad are active both in drugs trafficking and the trafficking and smuggling of human beings. It is sometimes difficult to distinguish between ethnic Albanians and Albanians who are or were citizens of the state of Albania. However, apparently all other criminal groups are co-operating with Albanian criminal groups.

\section{Some recommendations}

- legislation

It is desirable to ensure that there is a common interpretation regarding the applicability of the legislative framework provided by international and national legislation to cases of the internal trafficking of human beings.

- improvement of the operational capacity of the ASP

Develop a proactive approach in investigations of trafficking-related offences based on intelligence-led investigative techniques without reliance solely on the testimony of victims.

- strengthening inter-agency co-operation

Involve all the relevant ministries and governmental bodies in drafting amendments to the relevant legislative acts. Improve co-operation between prosecution offices and courts and victim assistance providers to provide information regarding the results of proceedings.

- strengthening regional and international police co-operation

Strengthen bilateral, regional (western Balkan) and international police co-operation in order to exchange operational information and experience on the development of patterns and trends in the trafficking of human beings.

- sustainability of capacities within ASP

Eliminate the frequent changes and transfers within the respective ASP structures in order to maintain the knowledge and skills delivered and obtained through training initiatives. 


\section{References}

Arben Tabaku (2005) 'Organised crime in Albania: a detrimental force to its social and economic development' South-East Europe Review for Labour and Social Affairs Issue 8(4): 123-132.

ASP/Directorate of the Fight against Organised Crime and of Witness Protection: Annual Reports 2001, 2002, 2003, 2004, 2005, 2006 and 2007 (January-September).

Beryl Nicholson (2002) Economic migration and asylum: a case for rethinking immigration policies.

Europol (2007) Organised illegal migration into the European Union January.

Lenka Krsikova (PAMECA Internship Programme) (2006) Evaluation of situation with regard to trafficking in human beings in Albania 2001-2006 November.

PAMECA Albania progress report 2005, 2006 \& 2007.

US State Department (2007) Trafficking in persons report June. 